\title{
Political Influence and Bureaucratic Autonomy
}

\author{
Kutsal Yesilkagit $\cdot$ Sandra van Thiel
}

Published online: 14 June 2008

(C) The Author(s) 2008

\begin{abstract}
The establishment of autonomous public bodies during the past two decades has created a highly fragmented public sector. Using a dataset with more than 200 Dutch public sector organisations, this article examines three related sets of questions: to what extent a relationship exists between formal and de facto autonomy; the level of influence that interested parties exert upon those organizations; whether a relationship exists between levels of formal and de facto autonomy and the level of influence exercised by these parties. We find that formal autonomy does not reinforce de facto autonomy; organizations with less autonomy report higher levels of political influence when policy autonomy is concerned; and that organizations with more autonomy report higher societal influence on their financial autonomy.
\end{abstract}

Keywords Bureaucratic autonomy $\cdot$ Political control $\cdot$ Public sector organizations

The political control of public administration is one of the most central concerns of students of politics and administration since the days of Wilson and Weber. On both sides of the Atlantic, fear of unresponsive and runaway bureaucracy has prompted several research endeavors in the past century leading to much bureaucrat-bashing (Niskanen 1971). Ironically, the implementation of a neo-liberal agenda within the public sector, i.e. privatizations, liberalization and New Public Management, further deepened skepticism about responsive bureaucracy instead of bringing the bureaucrat under control-which was the alleged objective. Political reformers hived off departmental units from ministries, created highly specialized organizations, and delegated substantial degrees of autonomy to these bodies (Pollitt and

K. Yesilkagit $(\square)$

School of Governance, University of Utrecht, Bijlhouwerstraat 6, 3511 ZC Utrecht, The Netherlands e-mail: a.k.yesilkagit@uu.nl

S. van Thiel

Erasmus University Rotterdam, P.O. Box, 1738, room M8-27, 3000 DR Rotterdam, The Netherlands e-mail: vanthiel@fsw.eur.nl 
Bouckaert 2004; Majone 1994; Levi-Faur 2005). The creation of autonomous and specialized bodies diminished leverage for political control and increased problems of coordination within the public sector (Christensen and Laegreid 2006). Today, the public administrations of advanced capitalist economies offer a fragmented and multifaceted view: the public sector is inhabited by a multitude of organizations with different designs, created by different legal instruments, and with different financial and budgetary regimes (OECD 2002; Whettenhall 2003). The quest for political control has become even larger than it was several decades ago.

However, to what extent is this rather pessimistic view of regulatory reform true? Has the state really been "hollowed out"? Did the large-scale decentralizations, privatizations and agencifications during the 1980s and 1990 s really bring "potentially dramatic changes" for the "capacity [of the central state] to steer the system - its capacity for governance" (Rhodes 1994: 149)? The "hollowing out the state' thesis states that the central state has become one of the many public and private actors active within policy networks. The center can no longer govern by command but must rely upon its negotiation and persuasive skills because policymaking involves so many (new) stakeholders (Weller et al. 1997). While the reforms that were implemented during these years did have a lasting impact on relationships between politicians and bureaucrats, many authors argue that these changes did not lead to a hollowing out, but rather a reassertion of the center. Tendencies towards hollowing out the state have been countervailed by more "regulation inside government" (Hood et al. 1999). The central state put a halt to the dissipation of powers and discretionary authority to (semi)-autonomous agencies by strengthening internal controls and monitoring systems. And finally, new reforms such as the "whole-of-government" programs or the search for "joined-up" government were implemented to restore central control (Halligan 2006; Christensen and Laegreid 2007).

In this article we will examine the influence of political actors on public sector organizations in the Netherlands. We will present findings of a survey conducted among 219 semi-autonomous public sector organizations in this country. The majority of these organizations are fully or semi-autonomous from political oversight and have been created during the past twenty years. We are particularly interested in the following three sets of questions: (1) What is the relationship between the formal and de facto autonomy of public sector organizations in the Netherlands? Are formally more autonomous organizations also de facto more autonomous? The second set of questions concerns the extent to which actors or stakeholders in the environment of these organizations affect the autonomy of these organizations: (2) Which venues of influence, i.e. important stakeholders/actors, do exist in the environment of public sector organizations and how much influence do they exert on these organizations? Our third and final question focuses on the relationship between the perceived degree of influence exerted by these venues and the level of autonomy reported by these organizations: (3) Are organizations with more formal autonomy influenced less by actors (e.g. their stakeholders) in their environment?

These questions will be addressed in separate sections. But first we will discuss a body of literature that is of American origin but which has developed into a number of important systematic approaches to model to measure the relationships between political control and bureaucratic autonomy. Then we will describe the background 型 Springer 
of our case study (the Dutch parliamentary system and the examined public sector organizations) and this study's methodology (i.e. survey analysis). The article ends with a conclusion.

\section{Analyzing influence on public sector organizations: an overview of US studies}

While there is no shortage of academic studies on the relationship between politicians and public bureaucracy in parliamentary systems, there are relatively few studies that offer systematically collected and analyzed data on political influence and bureaucratic autonomy. Mainstream research in the field of politicaladministrative relationships in parliamentary settings is descriptive and institutional at heart (Pollit and Bouckaert 2004; 't Hart and Wille 2006; Peters and Pierre 2004).

It is for this reason that we turn to US studies of political influence. There, studies of political influence formed a reaction to the view that bureaucracy was out of control. It was assumed that Congress would fail to control the bureaucracy because of "the haphazard nature of the oversight activities that did take place, the lack of expertise by members of Congress and their staffs, and the disregards of bureaucrats for their members" (Miller 2005: 209). The 'congressional dominance' literature showed however that Congress was actually able to exert control over the bureaucracy, both ex post and ex ante. Ex post control occurred through the appropriation process, legislation and legislative changes, and oversight hearings (Weingast and Moran 1983; Kiewiet and McCubbins 1991) and ex ante controls were found in agency design, administrative procedures, audits and compulsory reporting (McCubbins 1985; McCubbins et al. 1987). The debate revolved around the question whether Congress should apply a "police patrol" or "fire alarms" approach, i.e. whether Congress should pro-actively monitor agencies (patrol) or whether it should wait until interest groups would rung the bells about agency (mis) behavior (McCubbins and Schwartz 1984). In response to the congressional dominance school, presidential influence theories of political control argued that Presidential influence on bureaucracy flowed through the authority to appoint agency directors, reorganization, and budgetary powers (Moe 1985; Lewis 2003).

Both congressional dominance and presidential influence studies, however, focused on just one single principal and one single agent. By contrast, Hammond and Knott (1996: 163) concluded that bureaucratic autonomy is a "contingent matter" depending on the strategies pursued by the President, the House and the Senate. Under some circumstances agencies may enjoy more autonomy than under other circumstances, but political control is always a matter of "joint custody" of president, Congress and the courts (Wood and Waterman 1991; Hammond and Knott 1996; Furlong 1998). Therefore, political influence should be modeled in terms of 'venues of influence', because bureaucratic agencies report to be influenced by "differently perceived sets of principals" (Waterman et al. 1998: 19).

So, there are more actors than formal governmental principals alone, for example interest groups, clients and citizens, courts and the media. Furlong (1998) has measured the relative influence of these actors, the president and Congress on twelve federal agencies. He asked randomly selected respondents from the agencies to rate the relative influence of the different actors and found a clear distinction between the 
influence of Congress and the president on the one hand, and the courts, interest groups and the general public on the other. He found that Congress and president, the two core political principals, have the highest influence on public organizations. Waterman et al. (1998) support these findings. In two surveys, they asked the employees of two environmental protection agencies to rate the degree of influence on their agency by a number of political and administrative actors and found that "agents do not perceive that influence is exerted solely by each separate principal in a dyadic fashion; rather bureaucrats perceive that certain types of principals ... exert similar forms of influence" (Waterman et al. 1998: 23)

\section{Political influence analysis in a parliamentary context: The Netherlands}

In this article, we will follow a similar approach as Furlong and Waterman et al. Our aim is to partially replicate these studies but now for a parliamentary system, namely the Netherlands. There are several reasons why the Dutch case is interesting. First, the Dutch political system is a parliamentary democracy of the consociational type. Over time, it has consistently produced multiparty governments that were founded upon stable, often oversized, parliamentary majority coalitions (Lijphart 1999; Andeweg and Irwin 2005).

An important difference compared to the US system is the ministerial portfolio system. In the US presidential system a clear separation of powers between the executive and legislative branches juxtaposes President and Congress on a relatively equal footing. In the Dutch parliamentary system however, the legislature and the executive are more or less 'lined up' with the latter being fully responsible and dependent upon the legislature through a vote of confidence. ${ }^{1}$ A singular chain of delegation runs from voters to parliament, from parliament to cabinet, from cabinet leadership to individual minister, and from the individual minister to the bureaucracy. This is known as the "the singularity principle" (Strøm 2000). At the executive end of the chain, individual ministers are the "relevant privileged actors" (Laver and Shepsle 1996). This system makes a minister an agent of parliament but at the same time a principal for the bureaucracy that is assigned to her portfolio. The autonomy of bureaucratic agencies is hence significantly dependent on the formal powers of the minister, as ministers are ultimately responsible for the decisions, actions and behaviour of bureaucrats residing under their authority.

Interest groups may also exert influence upon public sector organizations. Ideallytypically, interest groups in the US compete for access to governmental decisionmaking centers. In Europe, politicians delegate formal authority to representatives of interest organizations to take part in formal policymaking processes. Interest organizations are represented in extra-parliamentary consultative bodies and in the governing boards of executive agencies. They are co-producers of public policies together with governmental actors in the areas of their interest. Of course, neither the US nor the European system can be characterized as purely pluralist or purely corporatist-there are much more flavors than these two (van Waarden 1992).

\footnotetext{
${ }^{1}$ This is the case in the Netherlands. In other parliamentary democracies, e.g. where minority governments are the norm such as in Scandinavian countries, the situation is somewhat different.

Springer
} 
Moreover, the relationships between interest groups and politics are not static and change over time (Christiansen and Rommetvedt 1999; Molina and Rhodes 2002). Whatever the shape of pressure group politics, interest groups are expected to exert influence on public sector organizations.

Next to the aforementioned actors we will consider the role of consultants, public opinion, clients, target groups, and the media. The influence of consultants on public sector organizations is rarely studied, although in the Netherlands 760 million euro was spent in 2002 on external advice. Consultants study both organizational reforms and policy evaluations, and may thus exert influence on public sector organizations. The media may exert political influence by bringing news, i.e. events and possible scandals, to the fore. The impact of the media on public sector organizations however is expected to run through political channels, i.e. by parliamentarians confronting ministers with the news. Citizens have frequent contacts with public sector organizations as clients or as target groups. We therefore expect that public organizations with large client groups will be affected by their clients. Finally, seemingly indirect and deluded, but nevertheless important may be the influence of public opinion.

\section{Methodology}

\section{Survey administration}

In May-June 2006 we carried out a survey among Dutch public sector organisations. The web-based questionnaire consisted of 50 questions on different topics including, among others, agencies discretionary authority to select target groups and policy instruments; the financial system in use; third party influence; participation in the EU policy process; audit and accountability arrangements; organizational culture; influence on the development of new policies; position and role of the board; and the use of a large number of management techniques like performance indicators, HRM and quality care. ${ }^{2}$ In this paper we only use the data that pertain to autonomy and external influence. Data were analysed using SPSS 15.0.

We sent the survey to all known public sector organizations in the Netherlands. ${ }^{3}$ 621 organisations were identified using earlier research and government documents and websites. Of 47 organizations the addresses were wrong (29); 8 organizations declined to cooperate. In the end, the survey was send to 574 organizations. The survey was filled out by respondents from 219 organizations, of which 14 returned the questionnaire by mail (total response rate $38 \%$ ). ${ }^{4}$ We eliminated one group of organizations, namely Statutory Trade Associations and Water Boards because

\footnotetext{
${ }^{2}$ This questionnaire is part of an international comparative study into the autonomy and steering of public sector organizations (PSOs). The survey had been carried out before in Belgium, Norway, and Ireland (see www.publicmanagament-cobra.org). The survey focuses on PSOs at national level only.

${ }^{3}$ Of course, some minor organizations may well have been overlooked. The dataset, however, contains the most comprehensive overview of these bodies in the Netherlands for the period under research (2006).

${ }^{4}$ As the response rate for the different types of public sector organisations was not statistically significantly different from their proportion in the population, the sample is considered representative.
} 
of their special constitutional position. This caused a drop in the response rate of only $2 \%$.

The survey raises some potential concerns. The first and perhaps most important concern is that this is a survey with which we aim to measure something that in reality may be dynamic and highly political: the autonomy of agencies. The level of autonomy is often contingent upon specific political situations and developments. Events or crises may suddenly emerge and lead ministers to renege on the agreed upon terms of autonomy (Majone 2001). A survey cannot capture political salience in such a dynamic fashion. However, we can assume that the representative sample of public sector organizations in our dataset also shows a cross-section of politically salient and non-salient organizations and/or tasks.

There are three more issues regarding the representativeness of our data. First, the response rate per question varies. For example, the question concerning the autonomy of the organization in selecting a policy's target group was answered by 143 respondents $(25 \%)$ but a similar question about choosing policy instruments by only 108 organizations (19\%). This may cause bias. Therefore, we have weighted responses per type of organization and thus simulated proportionate responses from each type of organization. We did not find any statistically significant differences between the weighted and unweighted samples, though, so bias will be limited. Second, 85 organizations (39\%) belonged to a cluster of organizations; regionally based independent bodies with the exact same legal basis. ${ }^{5}$ In order to correct for overestimation, we calculated aggregated values for each cluster. However, when we compared the results with non-aggregated values we found no significant difference. Third, we sent the survey to the directors of the organizations. $46 \%$ of the surveys were answered by the directors themselves. Some of the questions called for specific knowledge for example on financial and personnel issues and were therefore answered by qualified financial and personnel officers (4\%). In some cases, it was the assistant or secretary to the board of directors who filled in the survey questions $(23 \%)$. Some of the organizations are headed by a chairperson, who was invited to fill out the questionnaire (12\%). Differences in type of respondents may obviously cause bias, but in the case when answering the questionnaire was delegated we assume that the person best suited to answer the survey was charged with it.

The organizations in the survey: formal autonomy

The organisations in the survey can be grouped into four categories, based on their legal statutes. This division coincides with an increasing degree of formal (legal) autonomy (cf. Christensen and Yesilkagit 2006:208): contract agencies, independent administrative bodies, legal entities with a statutory task and government foundations. Contract Agencies (in Dutch: agentschappen) have no legal personality and all their decisions are subject to full ministerial accountability. They are former directorates of ministries. Their autonomy is restricted to managerial decisions, within legal and financial boundaries. For example, they can use an accrual accounting system and save 'profits' from one year for investments in the next

\footnotetext{
${ }^{5}$ Land commissions, universities, chambers of commerce, police regions, museums, food quality control agencies, and adult and vocal training centers.
}

Springer 
year-to a maximum of $5 \%$ of total revenues. Contract agencies cannot however borrow money or participate in a limited company.

Independent Administrative Bodies (in Dutch: ZBOs) have more managerial freedom than contract agencies. Almost all ZBOs have legal personality, based on public (about $60 \%$ of cases) as well as private law (about $40 \%$ ). Their performance is only in part subject to ministerial accountability; the Minister of the parent department is responsible for the policy that is implemented by the $\mathrm{ZBO}$, the decision to charge a ZBO with this task and the supervision of the ZBO. All other aspects of performance-like customer service and target setting - are up to the ZBO. Performance agreements are laid down in annual contracts or other documents.

Legal Entities with a Statutory Task (in Dutch: RWT) are statutory bodies with legal personality, either based on public or private law. In practice, most of these bodies are school boards. We have not included boards of primary and secondary schools into our survey because their numbers would complicate statistical analyses too much (about 2500 boards exist in The Netherlands). All higher education RWTs were included though. Other examples of RWTs are museums and university hospitals. RWTs are independent organisations, which are appointed by law to carry out a particular public task for which they receive funding from the government.

Finally, government foundations (in Dutch: overheidsstichtingen) are foundations established by or on behalf of the government, and were involved in some sort of public task. Foundations have legal personality based on private law, and are managed by a board. The Dutch government hardly ever appoints government representatives on these boards. Foundations in our sample are on average small organisations, partly run by volunteers. They include examples like organisations of military veterans, and supporters of a museum. Several ZBOs and RWTs are also government foundations; in case of overlap foundations have been listed only in the ZBO or RWT category.

Measuring autonomy and political influence

Of the various dimensions of autonomy, such as policy, financial, structural, personnel, and legal (see Christensen 2001; Verhoest et al. 2004), we will focus only on policy and financial autonomy. Table 1 lists our measures. Organizations were ranked high on policy autonomy if they can choose the target groups and instruments for the policies they implement independently from the minister of parent department, and when they are (pro)-actively involved in the policymaking process. The financial autonomy of organizations was measured as the level of discretion to obtain loans from the capital market; to set tariffs for products and/or services; freedom to join partnerships with other entities under private law; to shift between running costs and program costs on their budgets; and to shift their budget over time, i.e. between budget years. Finally, we asked respondents to estimate the influence on the agency by certain actors, by rating them on a 3-point scale ("To what extent is your organization's policies influenced by [actor's name]?", scale $1=$ not, 2 = to some degree, $3=$ to a large degree). We have divided these actors as governmental (i.e. parliament, cabinet, minister of parent department, minister of finance, other ministers) and non-governmental actors (i.e. clients, interest groups, consultants, media, public opinion). 
Table 1 Description and measurement of policy and financial autonomy variables

\begin{tabular}{|c|c|c|}
\hline Dimension of autonomy & Operationalisation & Survey question \\
\hline \multirow[t]{3}{*}{ Policy autonomy } & $\begin{array}{l}\text { Discretion to choose } \\
\text { target group }\end{array}$ & $\begin{array}{l}\text { Influence of organization on choice of } \\
\text { target groups (scale } 1=\text { Ministry chooses } \\
\text { independently ... } 5=\text { Organization } \\
\text { chooses independently) }\end{array}$ \\
\hline & $\begin{array}{l}\text { Discretion to choose } \\
\text { policy instrument }\end{array}$ & $\begin{array}{l}\text { Influence of organization on choice of } \\
\text { policy instrument (scale } 1=\text { Ministry } \\
\text { chooses independently ... } 5=\text { Organization } \\
\text { chooses independently) }\end{array}$ \\
\hline & $\begin{array}{l}\text { Involvement in } \\
\text { policymaking process }\end{array}$ & $\begin{array}{l}\text { To which extent is organization involved in } \\
\text { policy making? (scale } 1=\text { not at all } \ldots \\
5=\text { always, we take often initiative) }\end{array}$ \\
\hline \multirow[t]{5}{*}{ Financial autonomy } & $\begin{array}{l}\text { Obtaining loans from } \\
\text { capital market }\end{array}$ & $\begin{array}{l}\text { Can the organization obtain loans } \\
\text { independently? (scale } 1=\text { no, } 2=\text { after } \\
\text { approval of ministry, } 3=\text { yes) }\end{array}$ \\
\hline & $\begin{array}{l}\text { Setting tariffs for } \\
\text { products \& services }\end{array}$ & $\begin{array}{l}\text { Can the organization set tariffs for products } \\
\text { and services independently? (scale } 1=\text { no }\end{array}$ \\
\hline & $\begin{array}{l}\text { Participation in } \\
\text { private entities }\end{array}$ & $\begin{array}{l}\text { Can the organization participate in private } \\
\text { entities independently? (scale } 1=\text { no } 2=\text { after } \\
\text { approval of ministry, } 3=\text { yes) }\end{array}$ \\
\hline & $\begin{array}{l}\text { Shifting running \& } \\
\text { program cost budgets }\end{array}$ & $\begin{array}{l}\text { Can the organization shift its budget between } \\
\text { running and program costs independently? } \\
\text { (scale } 1=\text { no } 2=\text { after approval of ministry, } \\
3=\text { yes) }\end{array}$ \\
\hline & $\begin{array}{l}\text { Shifting budgets } \\
\text { over time }\end{array}$ & $\begin{array}{l}\text { Can the organization shift its budget over } \\
\text { time independently? (scale } 1=\text { no } 2=\text { after } \\
\text { approval of ministry, } 3=\text { yes) }\end{array}$ \\
\hline
\end{tabular}

\section{Results}

We will first present findings on the relationship between formal and de facto autonomy. For each type of public sector organization we have measured the mean level of policy and financial autonomy, as our respondents perceive this. We then move on to the perceived levels of influence as exerted by various governmental and non-governmental actors. Finally, we will correlate the perceived levels of autonomy with perceived levels of external influence.

\section{Formal and de facto autonomy}

To what extent does the formal autonomy of a public sector organization adequately reflect the organization's actual or de facto level of autonomy? Do organizations with high formal autonomy, also have more de facto autonomy? Table 2 presents the means and ANOVA statistics for policy autonomy. Only involvement in departmental policymaking and the discretion to select policy instruments are statistically significant different for the various types of organizations; the effect of selecting instruments is the strongest. Furthermore, contrary to our expectation, de facto policy autonomy does not increase with formal policy autonomy. Contract agencies are more involved in departmental policymaking than governmental foundations, and independent administrative bodies more than any other type of organization. We 
Table 2 Actual involvement in policy-making and use of policy-making discretionary power to select target groups and policy instruments vis-à-vis own ministry, measured per type of organization

\begin{tabular}{llll}
\hline Type of organization & $\begin{array}{l}\text { Involvement in } \\
\text { policymaking: }\end{array}$ & $\begin{array}{l}\text { Discretion to select } \\
\text { target groups: Mean }\end{array}$ & $\begin{array}{l}\text { Discretion to select policy } \\
\text { instruments: mean }\end{array}$ \\
\hline Contract agencies & $3.27(0.65)$ & $3.55(1.21)$ & $3.90(1.37)$ \\
Independent administrative bodies & $3.72(0.97)$ & $4.40(1.43)$ & $5.09(0.99)$ \\
Legal entities with statutory tasks & $3.00(1.06)$ & $4.48(0.85)$ & $5.00(0.57)$ \\
Government foundations & $3.19(1.26)$ & $4.43(1.10)$ & $4.32(1.22)$ \\
& $F=3.157$ & $F=1.709$ & $F=5.681$ \\
& $p=0.027$ & $p=0.169$ & $p=0.01$ \\
Total $(N)$ & 122 & 115 & 102 \\
\hline
\end{tabular}

For involvement: $0=$ Not at all and $5=$ Always, because we often take initiative ourselves. For both policy autonomy measures: $0=$ Ministry takes most decisions, independent from us, and $6=$ We take all decisions, no involvement ministry. Organizations belonging to a cluster have been ascribed the mean value of their cluster (note: none of the contract agencies belongs to a cluster). We found no significantly different results. Means, standard deviations in brackets

would expect that the closer an organization is to the minister (i.e. less formal autonomy), the less policy autonomy it would have. However, these findings suggest that closeness to the policymaking center is more important than having (formal) autonomy. ${ }^{6}$

This effect is replicated for the discretion to select target groups; organizations at a greater distance from the ministerial department report higher levels of discretion (although n.s.). There appears to be a divide between contract agencies on the one hand and other public sector organizations on the other hand. Being at arms' length significantly affects the respondents' perception of autonomy. ${ }^{7}$ In sum, there is no linear relationship between formal and de facto autonomy. Distance from the ministerial department as such is not reflected in the levels of policy autonomy.

Table 3 presents the findings for financial autonomy. Except for setting tariffs and shifting budgets over time, contract agencies enjoy the least autonomy from their parent department compared to the other organizations. Contract agencies have lesser degrees of autonomy when it comes to obtaining loans from capital markets, the discretion to participate in private entities such as public-private partnerships, and the shifting between running and program costs within their own budget without prior consent of the parent department. Regarding the autonomy to shift budgets over time, contract agencies have been explicitly designed so as to be freed from the input line-item budgets (Van Thiel and Pollitt 2007).

The most remarkable finding in this table is therefore perhaps the observation that contract agencies enjoy substantially more discretion to set tariffs than inde-

\footnotetext{
${ }^{6}$ A multiple comparisons test shows that two groups differ from each other, i.e. independent administrative bodies and legal entities with a statutory task, albeit in a very weak sense as $p=0.063$. This is confirmed by a $t$-test: $t=2.963, p=0.023$.

${ }^{7}$ A multiple comparison test shows that the mean differences between contract agencies and independent administrative bodies $(p=0.010)$ and between the latter and government foundations $(p=0.017)$ differ significantly for each other. If we relax the level of significance we also find that the mean differences between contract agencies and legal entities with a statutory task $(p=0.059)$ significantly differ from each other.
} 
Table 3 Mean rankings of degrees of various measures of financial autonomy

\begin{tabular}{|c|c|c|c|c|c|}
\hline $\begin{array}{l}\text { Type of } \\
\text { organization }\end{array}$ & $\begin{array}{l}\text { Obtaining loans } \\
\text { for investment }\end{array}$ & $\begin{array}{l}\text { Setting tariffs } \\
\text { for products } \\
\text { and services }\end{array}$ & $\begin{array}{l}\text { Participation } \\
\text { in private } \\
\text { entities }\end{array}$ & $\begin{array}{l}\text { Shifting running } \\
\text { and program } \\
\text { cost budgets }\end{array}$ & $\begin{array}{l}\text { Shifting } \\
\text { budgets } \\
\text { over time }\end{array}$ \\
\hline Contract agencies & $2.17(0.83)$ & $2.08(0.49)$ & $1.69(0.75)$ & $1.83(0.72)$ & $2.38(0.65)$ \\
\hline $\begin{array}{l}\text { Independent } \\
\text { administrative } \\
\text { bodies }\end{array}$ & $2.42(0.78)$ & $1.86(0.73)$ & $2.00(0.72)$ & $2.36(0.76)$ & $2.34(0.75)$ \\
\hline $\begin{array}{l}\text { Legal entities } \\
\text { with statutory } \\
\text { tasks }\end{array}$ & $2.80(0.17)$ & $2.40(0.15)$ & $2.76(0.28)$ & $2.83(0.05)$ & $2.84(0.27)$ \\
\hline $\begin{array}{l}\text { Government } \\
\text { foundations }\end{array}$ & $\begin{array}{l}2.67(0.73) \\
F=3.416 \\
p=0.019\end{array}$ & $\begin{array}{l}2.70(0.66) \\
F=15.509 \\
p=0.000\end{array}$ & $\begin{array}{l}2.50(0.81) \\
F=11.478 \\
p=0.000\end{array}$ & $\begin{array}{l}2.63(0.67) \\
F=7.576 \\
p=0.000\end{array}$ & $\begin{array}{l}2.35(0.79) \\
F=3.405 \\
p=0.020\end{array}$ \\
\hline Total $(N)$ & 138 & 135 & 139 & 126 & 142 \\
\hline
\end{tabular}

Can you $\ldots 1$ = No, 2 = Only after approval of ministry, $3=$ Yes

Means, standard deviations in brackets

pendent administrative bodies (ZBOs 2.08 versus contract agencies 1.86 , but n.s. based on a multiple comparison test). The majority of legal entities with statutory tasks and government foundations are institutes of higher learning that set their tariffs for academic years and other courses, which explains these categories' high ranking.

In conclusion, although not all differences are statistically significant, the findings show that there is no linear relationship between the formal autonomy of an organization and its de facto autonomy in a number of dimensions of policy and financial autonomy. The findings suggest that in practice, public sector organizations operate under different degrees of autonomy, regardless of their formal (legal) position.

Formal autonomy and venues of influences

Next we will examine the respondents' rating of the level of influence of external political actors on their organization. We expect that organizations with more formal autonomy will report a lower level of influence from political actors. The results are displayed in Table 4. Except for the influence of the cabinet and interest groups, none of the findings are statistically significant (at the $90 \%$ and/or $95 \%$ level).

Table 4 leads to the following observations. First, the minister of the parent department is seen as the most influential political actor. This is what we could expect on the basis of the formal power structure within parliamentary systems. If we look at the means for each type of organization, we see that ministerial influence is reported highest, again as expected, by contract agencies followed by legal entities with a statutory task, independent administrative bodies and government foundations.

Second, the political actor that is overall rated as having the lowest level of influence is, surprisingly, the minister of finance (1.59). This is unexpected as the minister of finance is generally considered as one of the main veto players, next to the prime minister. Still, and as expected, of the different types of organizations, 


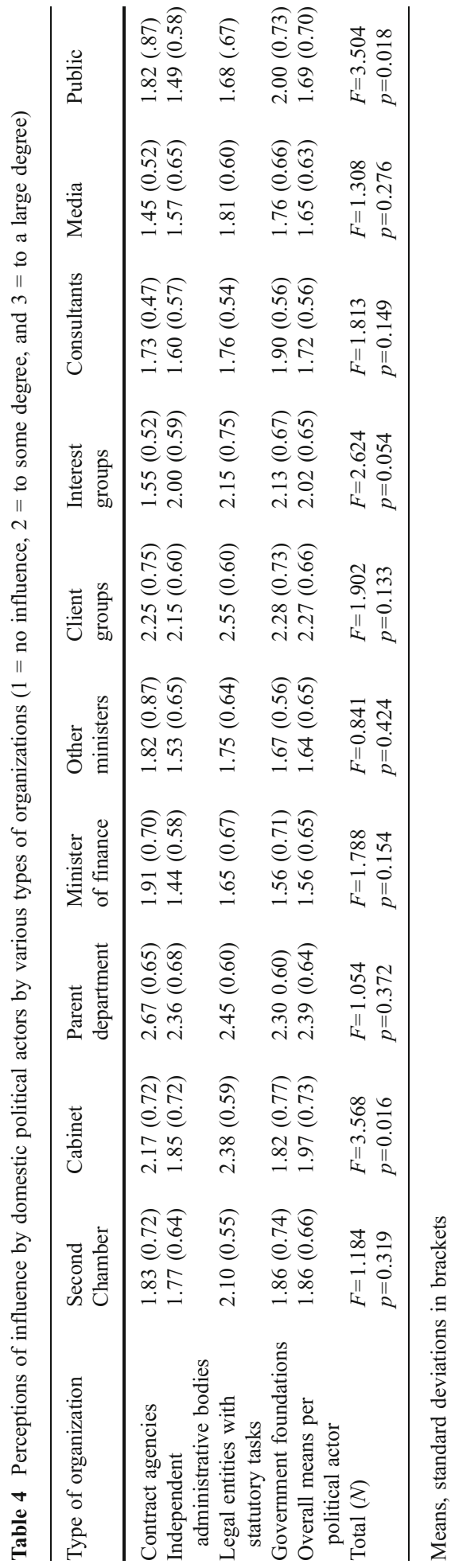


contract agencies rate the minister of finance as the most influential actor compared to other agencies.

One explanation for the low ranking of the finance minister may be that his position is equated with cabinet (2.39). The minister of finance plays a pivotal role in the cabinet's collective decision-making (Andeweg and Irwin 2005). Finally, the overall mean rankings show that the most influential actors on organizational policymaking are the clients of the organizations and interest groups within their environment (2.27 and 2.06, respectively). Overall, this picture suggests that there are pockets of policymaking, or policy communities, whose members have a large say in the policies of the organizations. Ministers of the parent department, clients and related interest groups are considered more influential than parliament, the cabinet and other ministers, consultants and the media.

Who are the most influential actors per type of organization? For contract agencies, the minister of the parent department is by far the most influential actor. In the case of contract agencies this is not a surprise finding as contract agencies fall under the full ministerial accountability. This probably also explains the lower ratings by contract agencies of the influence of interest groups and the media; all such contacts are handled by the parent department. Client groups, however, remain highly influential. Some of the agencies are indeed providers of public services, such as the Tax Service, Prison Service and the Patent Office.

Although the independent administrative bodies (ZBOs) did also rate the minister of the parent department as the most influential actors, they rated cabinet, parliament, the finance minister and other ministers substantially lower than contract agencies. By contrast, ZBOs rated interest group influence much higher. This could be explained by the ZBOs' higher formal autonomy: as the minister is no longer responsible for all aspects of policy implementation, it is more rational for interest groups to approach independent administrative bodies than approaching the minister. Moreover, in some cases interest group representativeness are appointed in the boards or client panels of ZBOs. Overall, independent administrative bodies report to be subject to the lowest degrees of influence by external actors (overall mean influence score of 1.81).

Legal entities with a statutory task (RWT) seem to be most enmeshed in a web of influence. The overall mean for this type of organization is 2.07. This can be understood by recalling that most of these organizations are educational and research organizations, falling under the ministry of education and sciences, a spending department par excellence. These institutes require large sums of money and provide services to a large group of clients, i.e. students. Educational institutions are regularly subject to peer reviews of the quality of education and research.

Finally, whereas government foundations perceive themselves as relatively more autonomous from political supervision (cabinet, minister of parent department, finance minister and other ministers) they are more 'vulnerable' to outside influence such as consultants, media and interest groups. Interestingly, the mean score for parliamentary influence is more or less the same as for contract agencies.

In conclusion, like before our findings show a more mixed and complex relationship between political influence and formal autonomy than one would expect on the basis of the organizations' formal autonomy. First, in certain cases organizations with low formal autonomy report lower levels of influence than Springer 


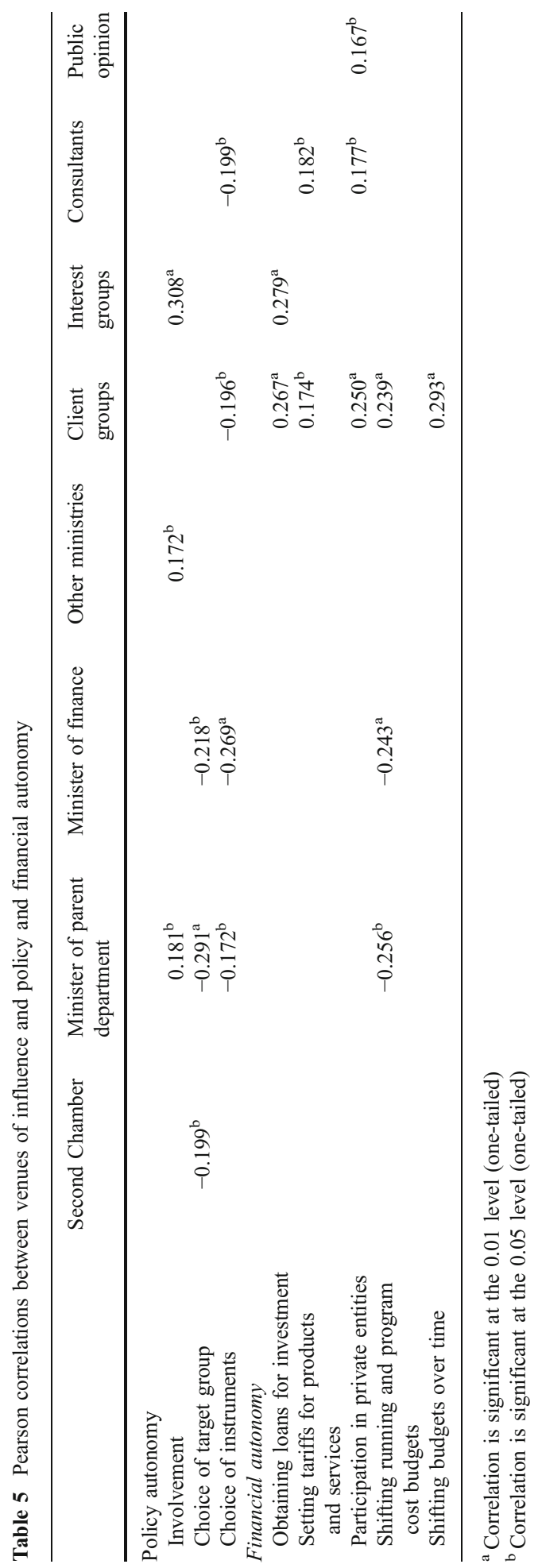


organizations with high formal autonomy and vice versa. Second, organizations with higher levels of formal autonomy did not report higher levels of influence from non-governmental actors and vice versa. Overall however formal political actors are rated as more influential than non-governmental actors. This is a corroboration of the previous findings of Furlong and Waterman et al. We will return to this point in the concluding section.

\section{Political influence and bureaucratic autonomy}

Finally, we have come to the third and final question: are organizations with more autonomy influenced less by actors in their environment? To answer this question we will examine the correlations between the levels of influence exerted by various actors and the various dimensions of autonomy. Table 5 presents the values of statistically significant correlations.

As for policy autonomy, we can make two observations. First, public organizations that are more involved in policymaking report a higher level of influence by the parent department's minister, other ministers and interest groups. This seems understandable as these are probably the most important parties involved in policy making. Second, other aspects of policy autonomy are negatively correlated to influence by the Second Chamber (parliament), the minister of parent department, the minister of finance, client groups and consultants. High influence of these actors seems to be inversely related to agencies' choosing target groups and instruments for the policies they implement. Whereas our findings for parliament and ministers match our expectations, the effect of consultant influence is less clear. Perhaps consultants advise systematically to award lower levels of autonomy, or offer only advice in line with ministerial preferences, i.e. the actors that usually hire external consultants.

As for financial autonomy, there is - surprisingly - hardly any influence of core political actors, except for the ability to shift between programme and running costs (which is influenced negatively). Client groups on the other hand seem to have an overall positive effect, suggesting that politicians delegate more financial autonomy to public organizations with potentially influential client groups. Interest groups are however of much lesser importance.

To sum up, we have again a mixed picture. Public sector organizations that report higher governmental influence have less formal policy autonomy but more de facto policy autonomy. Organizations with high degrees of financial autonomy are no more or less influenced by governmental actors (except for shifting programme and running cost budgets), but they do report consistently higher levels of client group influence. Perhaps client group influence is used as a substitute for direct governmental influence.

\section{Conclusion}

It has been proposed that decentralization, autonomization and specialization of public tasks and delegation of extensive discretionary powers to public organizations during the past decades would lead to a strong decline of the capacities of politicians 
to control the public sector. With more and more semi-autonomous public sector organizations being created, the potential for bureaucratic drift is believed to increase. However, despite the overwhelming attention that public sector reform enjoys among academics and practitioners, the extent to which these semiautonomous organizations have become more de facto autonomous from their political and societal environment has remained an empirical question. Therefore, this paper has examined the relationship between formal and de facto autonomy, the influence of a number of political actors on (semi)-autonomous public sector organizations, and the relationships between these levels of influence and levels of autonomy. Using survey data, we explored to which extent public sector organizations are adrift and have become unresponsive to the most important venues of influence in a parliamentary institutional setting.

Our study is explorative because little is known in comparison to the situation in the US. We have found a number of important (preliminary) insights that justify further research on this topic. In general, we have found the relationship between the key concepts of autonomy and control are more complex and less straightforward than generally thought of. First, the level of formal autonomy is not a straightforward indicator of the level of actual or de facto autonomy. Second, organizations that are formally located further away from the direct supervision of political stakeholders do not always report lower levels of autonomy than organisations that are located in the vicinity of political principals. Finally, our analysis has shown that higher levels of political control suggest lower levels of policy and financial autonomy, but not for each dimension of policy and financial autonomy. By the same token, higher levels of societal influence are found to correlate positively with most forms of policy and financial autonomy.

In comparison to the US studies, it is interesting to find that in a parliamentary setting formal political institutions are rated as the most influential actors too. What we do not know yet, however, is what the sources of the dominance of formal political institutions are in both systems. The instruments of political control of congress and president are different from those that ministers have in a parliamentary system like the Netherlands. While studies like Furlong and Waterman et al. give further insights into how political control in the US works, we need to ask the same question for parliamentary systems.

This brings us to our final point. Our findings suggest that the central state is far from "hollowed out"- has it ever been? Given the degree of influence that the agencies in this survey ascribe to central governmental actors in comparison to interest groups, clients and the media, we can infer that the center is still pretty much in control of the various (semi)-autonomous agencies in the Netherlands. The question remains is "how" is the center the dominant actor? The findings of studies on regulation inside government and of studies on the implementation of the wholeof-government and joined-up government are to some extent limited to the AngloSaxon world (Pollitt et al. 2007). Applying the theoretical models from the US literature to continental European systems could produce more insight into the mechanisms of control and steering within parliamentary systems generally.

We conclude with more questions than answers. One of the main questions that requires further research is to what extent levels of de facto autonomy correlate with the level of political salience of issues that agencies address in their policy programs. 
This requires a more dynamic approach to autonomy and control than we could do with our survey data. A more dynamic perspective could give us more precise insights into how agencies respond to external stimuli that are potentially threatening to the autonomy of the agency. In general, our study has shown that more systematic study is needed on the nature and mechanisms of autonomy and on the responsiveness of public sector organizations. Many of these organizations have far reaching policy and adjudicative autonomy and have powers to decide in individual cases. Still we do not yet know how these organizations make their decisions and whether these decisions are reflective of some of the interests of citizens and groups in society.

Open Access This article is distributed under the terms of the Creative Commons Attribution Noncommercial License which permits any noncommercial use, distribution, and reproduction in any medium, provided the original author(s) and source are credited.

\section{References}

Andeweg, R. B., \& Irwin, G. A. 2005. Governance and politics of the Netherlands. Basingstoke: Palgrave MacMillan.

Christensen, J. G. 2001. Bureaucratic autonomy as a political asset. In Peters, B. G., \& Pierre, J. (Eds.). Politicians, bureaucrats and administrative reform: 119-131. London: Routledge.

Christensen, T., \& Laegreid, P. 2006. Autonomy and regulation. Coping with agencies in the modern state. Chelthenham: Edward Elgar.

Christensen, T., \& Laegreid, P. 2007. The whole-of-government approach to public sector reform. Public Administration Review, 67(6): 1059-1066.

Christensen, J. G., \& Yesilkagit, K. 2006. Delegation and specialization in regulatory administration: A comparative analysis of Denmark, Sweden and the Netherlands. In Christensen, T., \& Lægreid, P. (Eds.). Autonomy and regulation. Coping with agencies in the modern state (chapter eight). Cheltenham: Edward Elgar.

Christiansen, P. M., \& Rommetvedt, H. 1999. From corporatism to lobbyism? Parliaments, executives and organized interest groups in Denmark and Norway. Scandinavian Political Studies, 22: 195-220.

Furlong, S. R. 1998. Political influence on the bureaucracy. The bureaucracy speaks. Journal of Public Administration, Research and Theory, 8(1): 39-65.

Halligan, J. 2006. The reassertion of the center in a first generation NPM system. In Christensen, T., \& Laegreid, P. (Eds.). Autonomy and regulation. Coping with agencies in the modern state: 161-180. Chelthenham: Edward Elgar.

Hammond, T. H., \& Knott, J. H. 1996. Who controls the bureaucracy? Presidential power, congressional dominance, legal constraints, and bureaucratic autonomy in a model of multi-institutional policymaking. Journal of Law, Economics, and Organization, 12(1): 121-168.

Hart, P. 't , \& Wille, A. 2006. Ministers and top officials in the Dutch core executive: Living together, growing apart? Public Administration, 84(1): 121-146.

Hood, C., Scott, C., James, O., Jones, G., \& Travers, T. 1999. Regulation inside government: Wastewatchers, quality police, and sleaze-busters. Oxford: Oxford University Press.

Kiewiet, D. R., \& McCubbins, M. D. 1991. The logic of delegation. Congressional parties and the appropriations process. Chicago: University of Chicago.

Laver, M., \& Shepsle, K. 1996. Making and breaking governments: cabinets and legislatures in parliamentary democracies. New York: Cambridge University Press.

Levi-Faur, D. 2005. The global diffusion of regulatory capitalism. Annals of the American Academy of Political and Social Science, 598(1): 12-32.

Lewis, D. E. 2003. Presidents and the politics of agency design. Political institutions in the United States government bureaucracy, 1946-1997. Stanford: Stanford University Press.

Lijphart, A. 1999. Patterns of democracy: Government forms and performance in thirty-six democracies. New Haven and London: Yale University Press.

Majone, G. 1994. The rise of the regulatory state in Europe. West European Politics, 17(3): 77-101. 
Majone, G. 2001. Two logics of delegation: Agency and fiduciary relations in EU governance. European Union Politics, 2(1): 103-122.

McCubbins, M. D. 1985. The legislative design of regulatory structure. American Journal of Political Science, 29: 721-748.

McCubbins, M., \& Schwartz, T. 1984. Congressional oversight overlooked: Police patrols versus fire alarms. American Journal of Political Science, 28(1): 165-179.

McCubbins, M. D., Noll, R. G., \& Weingast, B. R. 1987. Administrative procedures as instruments of political control. Journal of Law, Economics and Organization, 3: 243-277.

Miller, G. J. 2005. The political evolution of principal-agent models. Annual Review of Political Science, 8: 203-225.

Moe, T. M. 1985. Control and feedback in economic regulation: the case of NLRB. American Political Science Review, 79: 1094-1116.

Molina, O., \& Rhodes, M. 2002. Corporatism: The past, present and future of a concept. Annual Review of Political Science, 5: 305-331.

Niskanen, W. A. 1971. Bureaucracy and representative government. Chicago: Aldine, Atherton.

OECD 2002. Distributed public governance: agencies, authorities and other government bodies. Paris: OECD.

Peters, B. G., \& Pierre, J. 2004. Politicization of the civil service in comparative Perspective: the quest for control. London: Routledge.

Pollitt, C., \& Bouckaert, G. 2004. Public management reform: a comparative analysis. 2Oxford: Oxford University Press.

Pollitt, C., van Thiel, S., \& Homburg, V. 2007. New public management in Europe: adaptation and alternatives. Basingstoke: Palgrave MacMillan.

Rhodes, R. A. W. 1994. The hollowing out of the state: The changing nature of the public service in Britain. Political Quarterly, 65(2): 138-151.

Strøm, K. 2000. Delegation and accountability in parliamentary democracies. European Journal of Political Research, 37(3): 261-290.

van Thiel, S., \& Pollitt, C. 2007. The management and control of executive agencies: An Anglo-Dutch comparison. In Pollitt, C., van Thiel, S., \& Homburg, V. (Eds.). New public management in Europe: Adaptation and alternatives: 52-70. Basingstoke: Palgrave MacMillan.

van Waarden, F. 1992. Dimensions and types of policy networks. European Journal of Political Research, 21(1/2): 29-52.

Verhoest, K., Peters, G. B., Bouckaert, G., \& Vermeulen, B. 2004. The study of organisational autonomy: A conceptual overview. Public Administration and Development, 24(2): 101-118.

Waterman, R. W., Rouse, A., \& Wright, R. 1998. The venues of influence: A new theory of political control of the bureaucracy. Journal of Public Administration Research and Theory, 8(1): 13-38.

Weingast, B., \& Moran, M. 1983. Bureaucratic discretion or congressional control? Regulatory policymaking in the federal trade commission. Journal of Political Economy, 91: 765-800.

Weller, P., Bakvis, H., \& Rhodes, R. A. W. 1997. The hollow crown: countervailing trends in core executives. Basingstoke: Palgrave MacMillan.

Whettenhall, R. 2003. Exploring types of public sector organizations: Past exercises and current issue. Public Organization Review, 3: 219-245.

Wood, D. B., \& Waterman, R. 1991. The dynamics of political control of the bureaucracy. American Political Science Review, 85: 801-828.

Kutsal Yesilkagit is associate professor of Public Administration at the School of Governance at the University of Utrecht, the Netherlands. His research focuses on the institutional design of bureaucracy and political control and bureaucratic responsiveness. He has published in Public Administration, West European Politics and the Journal of Public Administration Research and Theory.

Sandra van Thiel is associate professor of Public Administration at Erasmus University Rotterdam, the Netherlands. Her research focuses on public management, in particular the rise and use of quasiautonomous organizations or executive agencies, both in the Netherlands and from a comparative perspective. Publications have appeared in Governance, Journal of Theoretical Politics and International Journal of Public Management. 